\title{
Młodzież z osiedli popegeerowskich a kształtowanie społecznych zasobów lokalnych
}

\section{Youth of former State Agricultural Farm estates as local human resources}

\section{Jadwiga BIEGAŃSKA ${ }^{1} \bullet$ Elżbieta GRZELAK-KOSTULSKA ${ }^{1} \bullet$ Mirek DYMITROW $^{2}$ Justyna CHODKOWSKA-MISZCZUK ${ }^{1} \bullet$ Stefania ŚRODA-MURAWSKA ${ }^{1}$ Krzysztof ROGATKA ${ }^{1}$}

${ }^{1}$ Uniwersytet Mikołaja Kopernika

Wydział Nauk o Ziemi, Katedra Studiów Miejskich i Rozwoju Regionalnego

ul. Lwowska 1, 87-100 Toruń

jadwigab@umk.pl•grzelak@umk.pl•jchodkow@umk.pl•steffi@umk.pl•krogatka@umk.pl

${ }^{2}$ University of Gothenburg

School of Business, Economics and Law, Department of Economy and Society, Unit for Human Geography P.O. Box 630; SE-405 30 Göteborg, Sweden

mirek.dymitrow@geography.gu.se

Zarys treści: Celem opracowania jest próba refleksji nad przyszłym kierunkiem rozwoju osiedli popegeerowskich (na przykładzie Chotla w gminie Izbica Kujawska, woj. kujawsko-pomorskie) oparta na analizie i ocenie aktualnych społecznych zasobów lokalnych reprezentowanych przez młodzież. W opracowaniu przyjęto, że kategoria ta w nieodległej perspektywie czasowej będzie wpływać na zasoby społeczne, te zaś przesądzą o tempie i kierunkach zmian obserwowanych na obszarach wiejskich. W związku z niepodważalnym faktem, że wsie popegeerowskie uważane są za jedne z najbardziej problemowych w planowaniu rozwoju obszarów wiejskich, a zasoby społeczne jej dorosłych mieszkańców cechuje brak więzi, zaufania i gotowości do współpracy, w opracowaniu podjęto próbę odpowiedzi na pytania: jakie są społeczne zasoby młodzieży mieszkającej w tego typu wsiach, czy zasoby te różnią się od zasobów społecznych ich rodziców i czy pozwalają one upatrywać szansy na poprawę sytuacji wsi popegeerowskich w przyszłości. Podjęta analiza ma charakter prognostyczny, co jest szczególnie istotne w przypadku obszarów problemowych. Szukając pewnych prawidłowości, można najogólniej wskazać, że w aspektach uznanych za zagrożenia dla rozwoju wsi popegeerowskich poglądy osób młodych i pozostałych członków społeczności są dość zbliżone, natomiast w kategorii szans rysują się istotniejsze różnice na korzyść osób młodych.

Słowa kluczowe: osiedla popegeerowskie, młodzież, zasoby społeczne, obszary wiejskie, rozwój. 


\section{Wprowadzenie}

Jednym z najważniejszych czynników decydujących o rozwoju obszarów wiejskich są ich zasoby ${ }^{1}$. Zasobem może być wszystko to, co może być i jest wykorzystywane przez jednostkę lub społeczność lokalną do realizacji jej potrzeb (Kosmaczewska 2009). W literaturze przedmiotu generalnie wyróżnia się pięć rodzajów zasobów i jednocześnie pięć podstawowych bogactw gospodarki lokalnej, a mianowicie zasoby: naturalne, społeczne, ludzkie, fizyczne i finansowe (Pretty 1998). Odniesienie do gospodarki lokalnej w kontekście zasobów nabiera szczególnego znaczenia w planowaniu rozwoju obszarów wiejskich, zwykle słabo zurbanizowanych, dysponujących mniejszym kapitałem inwestycyjnym, których modernizacja z powodu występujących tam barier nie nastąpi samoczynnie (Kożuch 2011). Zasób, aby przedstawiał wartość, musi podlegać bowiem prawom rynkowym, to z kolei oznacza, że może być on gromadzony i inwestowany lub też może być tracony (Kosmaczewska 2009). Z kolei o kierunkach i sposobach wykorzystywania zasobów, a zatem o ich potencjalnej aktywizacji, przesądzają przede wszystkim wspólnoty lokalne i ich decydenci. W tym znaczeniu kierunki i sposoby wykorzystywania zasobów bardzo mocno wpisują się w koncepcję rozwoju lokalnego, rozumianego z jednej strony jako łańcuch następujących po sobie zmian, obejmujący swoim zakresem potrzeby, hierarchie celów i wartości charakterystyczne dla danego obszaru oraz kreujący warunki dla bardziej efektywnego zagospodarowania zasobów lokalnych oraz przekształcania ich w czynniki rozwoju lokalnego przy udziale miejscowych społeczności w tworzeniu i kontroli realizacji procesów rozwoju, z drugiej zaś - jako pobudzanie ekonomicznej efektywności mieszkańców przez władze lokalne (Pomianek 2010). W uproszczeniu rozwój lokalny obejmuje prowadzenie działań na rzecz rozwoju społeczno-gospodarczego danej jednostki terytorialnej, z wykorzystaniem jej zasobów oraz uwzględnieniem potrzeb mieszkańców i przy ich udziale (Kożuch 2011). Działania na rzecz rozwoju społeczno-gospodarczego danej jednostki terytorialnej związane są także z polityką społeczną, czyli działaniami odgórnymi. R. Szarfenberg (2008) wyróżnia szerokie i wąskie pojmowanie polityki społecznej. W pierwszym znaczeniu polityka społeczna dotyczy kwestii związanych z pracą, zdrowiem, oświatą i wychowaniem oraz mieszkalnictwem. W wąskim znaczeniu natomiast koncentruje się na tzw. transferach socjalnych w postaci świadczeń pieniężnych (np. renty, zasiłki emerytury). W ogólnym rozumieniu system transferów socjalnych należy łączyć z łagodzeniem nierówności i ubóstwa w poziomie życia (konsumpcji), czyli państwem typu welfare state (opiekuńczym). Rola transferów socjalnych jest dyskusyjna, powodować może bowiem zamrożenie lub osłabienie zasobów społecznych, a w efekcie kapitału społecznego.

Wydarzenia, takie jak transformacja systemowa, a następnie akcesja Polski do UE, spowodowały, że polska wieś zaczęła funkcjonować w nowej rzeczywistości społeczno-gospodarczej, w której o sukcesie w dążeniu do poprawy warunków życia i konkurencyjności jednostek terytorialnych coraz rzadziej decydują zasoby naturalne. Niewystarczającym czynnikiem są nawet zasoby ludzkie. Najważniejszym czynnikiem determinującym kierunki rozwoju i możliwości szybkiego dostosowania się do nowych realiów gospodarczych są zasoby społeczne (por. Będzik 2008). Oznaczają one sieć powiązań, które pozostają do dyspozycji jednostek lub grup i potencjalnie mogą zostać zmobilizowane do realiza-

1 Oprócz zasobów, traktowanych jako endogenne czynniki rozwoju, o rozwoju obszarów wiejskich decydują również czynniki egzogeniczne, w tym: uwarunkowania historyczne, ogólny poziom rozwoju społecznoekonomicznego kraju, system gospodarki, polityka państwa i postęp techniczny (Churski i Perdał 2008). 
cji interesów indywidualnych lub grupowych. Zasoby społeczne obejmują zatem więzi społeczne, sieć powiązań między jednostkami, ich wzajemne zaufanie i gotowość do współdziałania oraz obecność autorytetów zdolnych do mobilizacji ludzkiej aktywności (Giza-Poleszczuk i in. 2000). Zasoby same w sobie nie przedstawiają większej wartości. Kluczowe jest ich używanie, a tym samym przekształcanie w kapitał społeczny. O ile bowiem zasoby społeczne obejmują to wszystko, co pozostaje do dyspozycji jednostki lub grupy, kapitał społeczny to zasoby uruchomione i wykorzystane przez te jednostki lub grupy w konkretnych działaniach². Zasoby społeczne stają się kapitałem społecznym, gdy jest na nie zapotrzebowanie, gdy uruchamiane są w działaniach i przynoszą wymierne efekty (Giza-Poleszczuk i in. 2000; Halamska 2008). Co więcej, jak zaznacza B. Fedyszak-Radziejowska (2006a, por. też 2006b), kapitał społeczny pozyskany na bazie zasobów jest ważny nie tylko ze względu na wymogi rynkowe, jest on także wyjątkowo istotny w kontekście radzenia sobie z traumą zmian społecznych. Umożliwia bowiem skuteczne podejmowanie akcji zbiorowych skierowanych przeciw warunkom traumatogennym, a ponadto wzmacnia poczucie tożsamości grupowej, mocy, siły przebicia po stronie pojedynczych obywateli. Aktywowane zasoby społeczne wydają się zatem kluczowe w kontekście wsi, z jednej strony jako remedium na zmiany, z drugiej jako istotny czynnik wpływający na jej rozwój.

Zasoby, w tym również społeczne, powodują, że wdrażanie idei rozwoju lokalnego w Polsce przebiegać może według różnych schematów. Obecnie za obszary sukcesu gospodarczego zwykło się uważać m.in. wielofunkcyjne obszary wiejskie stanowiące strefy podmiejskie dużych miast (por. Biegańska 2013; Szymańska i Biegańska 2013). Znaczną część obszarów wiejskich stanowią jednak tzw. obszary problemowe, będące strefami kumulacji szeregu niekorzystnych zjawisk społeczno-gospodarczych (Rosner 1999). W schemat ten wpisują się np. typowo rolnicze monofunkcyjne obszary wiejskie (Bański 2002). Jednak szczególnym przykładem obszarów problemowych, z uwagi na nawarstwienie barier związanych z rozwojem lokalnym, stanowią obszary wiejskie w przeszłości związane z funkcjonowaniem PGR-ów (Feltynowski i in. 2015; Biegańska i in. 2017; Dymitrow i in. 2017; Krzysztofik i in. 2017).

W Polsce w latach 1945-1989 PGR-y były najpowszechniejszą formą organizacji dużych gospodarstw rolnych (1112 jednostki o powierzchni od kilkudziesięciu do kilkunastu tysięcy km² - Ziętara 2005 za: Kraciński 2011, s. 41). Integralną częścią PGR-ów były osiedla mieszkaniowe stworzone z myślą o zaspokojeniu potrzeb bytowych zatrudnionych pracowników. Część z nich, szczególnie w Polsce centralnej i południowej (jak wytypowany do badania Chotel) stanowiła struktury heterogeniczne, tj. odmienne w aspekcie morfologicznym i społecznym od pozostałych obszarów wiejskich (fot. 1). W kontekście analizowania zasobów szczególnie istotna wydaje się być odrębność tego typu osiedli w aspekcie społecznym (por. Feltynowski i in. 2015; Biegańska i in. 2017; Dymitrow i in. 2017). Charakterystyczną ich cechą była m.in. względnie duża rotacja pracowników o różnym pochodzeniu, często zubożałych, różniących się obyczajami, co powodowało, że nie

\footnotetext{
2 Warto nadmienić, że zagadnienie tożsamości grupowej w kontekście kapitału społecznego zostało gruntownie przeanalizowane przez J. Putnama i in. (1993, 1995), którzy odnieśli kapitał społeczny do określonych cech organizacji społeczeństwa, jak: zaufanie, współpraca, zbieżne postawy, poglądy, przekonania oraz tradycja i normy kulturowe, które poprawiają sprawność i skuteczność społeczeństwa. Argumentowali jednocześnie, że społeczność, której członkowie są godni zaufania i ufają innym, tworząc sieć obywatelskiego zaangażowania, osiągają więcej niż grupa, w której brak powszechnego zaufania. Potwierdza to raz jeszcze, że kapitał społeczny należy traktować jako produktywny, tzn. taki, który może decydować np. o wzroście gospodarczym. Akcent postawiony przez autorów na społeczne aspekty rozwoju (będące w opozycji do oświeceniowego modelu rozwoju) wynika z możliwości konwersji kapitału społecznego w kapitał ekonomiczny.
} 
odczuwali oni więzi z miejscem zamieszkania (Sakson 2003). To powszechne poczucie tymczasowości panujące wśród rodzin pegeerowskich w porównaniu z zasiedziałymi rodzinami rolników indywidualnych nie sprzyjało społecznej integracji mieszkańców (Borowski 2013).

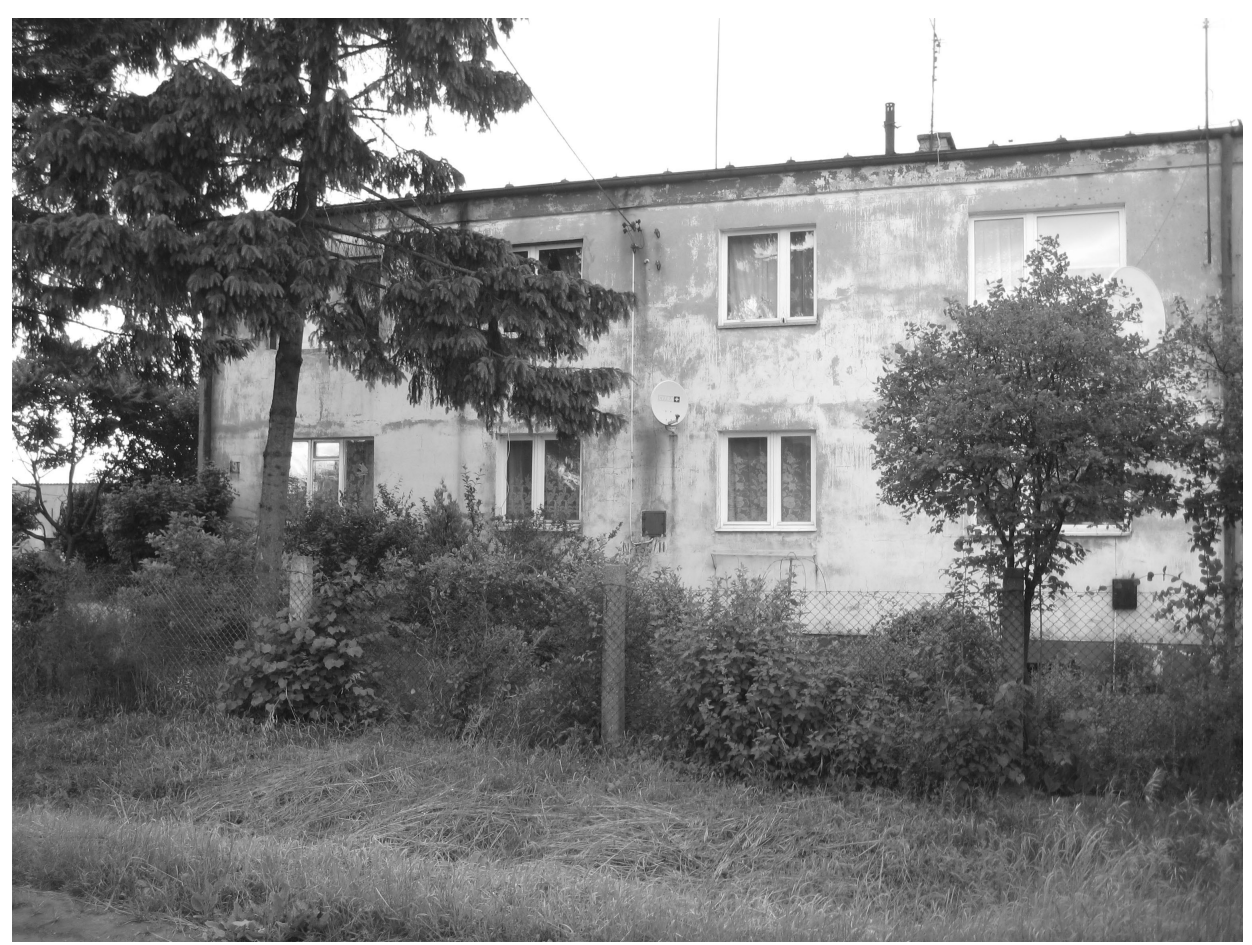

Fot. 1. Część budynków mieszkalnych na osiedlu popegeerowskim Chotel (fot. J. Biegańska) Part of residential buildings of the former State Agricultural Farm estate in Chotel

Zmiany polityczne i ekonomiczne w Polsce po 1989 roku spowodowały, że osiedla pegeerowskie szczególnie silnie odczuły skutki transformacji. Przeważającą ich część dotknęło: bankructwo, dewastacja majątku, odłogowanie, bezrobocie, wykluczenie społeczne, zjawiska społecznie patologiczne. Jak wskazują niektórzy badacze (Rosner 2002), obszary te uznać można wręcz za skrajny przykład problemów związanych z aktywizacją gospodarczą. Przyczyną tak trudnej sytuacji było przede wszystkim niedopasowanie monofunkcyjnych gospodarstw do nowych warunków ekonomicznych i w konsekwencji ich upadek, ale także wyizolowanie przestrzenne mieszkańców, którzy znaleźli się w wyjątkowo trudnej sytuacji pod względem dostępności do rynków pracy (Rosner 2007).

Efektem opisywanych zmian było ukształtowanie się środowiska o bardzo mało korzystnych dla młodzieży warunkach funkcjonowania i rozwoju. K. Szafraniec (2005) identyfikuje młodzież z tego typu obszarów jako obciążoną niższymi niż ich pozostali rówieśnicy aspiracjami, rezygnującą z planowania długofalowych strategii edukacyjnych, choć ujawniającą chęć osiągnięcia sukcesu mierzonego dobrobytem. Zwraca przy tym uwagę na pewne aspekty wynikające z przekazu międzypokoleniowego, bowiem, jak podkreśla, to rodzice odpowiedzialni są za przenoszenie na swoje dzieci postaw biernych, roszcze- 
niowych, pesymistycznych, nie wyposażając ich na starcie w żaden kapitał (materialny czy mentalny). Kontekst głębokiej systemowej zmiany potęgował zatem zarówno rosnący dystans między pokoleniami, jak i pogłębiające się zróżnicowania w pokoleniu młodzieży (Szafraniec 2005). Jak wskazano, obszary wiejskie w przeszłości związane z PGR-ami wymagają szczególnej uwagi badaczy jako tereny wysoce problemowe (najtrudniejsze w skali wszystkich obszarów wiejskich). Poszukiwanie dla nich skutecznych rozwiązań musi wynikać z pogłębionej znajomości ich specyfiki. W związku z tym celem niniejszego opracowania jest próba refleksji ${ }^{3}$ nad przyszłym kierunkiem rozwoju osiedli popegeerowskich oparta na analizie i ocenie aktualnych społecznych zasobów lokalnych reprezentowanych przez młodzież na przykładzie Chotla w gminie Izbica Kujawska w województwie kujawsko-pomorskim. W opracowaniu przyjęto, że młodzież w nieodległej perspektywie czasowej będzie wpływać na zasoby społeczne, bowiem jak twierdzi J. Forbrig (2005), jest ona najprawdopodobniej najważniejszą składową mechanizmu każdej zmiany społecznej ${ }^{4}$. Te zaś przesądzą o tempie i kierunkach zmian obserwowanych na obszarach wiejskich (por. Kwiecińska-Zdrenka 2004; Krzyminiewska 2009; Wagner 2012; Kallio 2016).

Pomimo że zasoby społeczne młodzieży wiejskiej - omawiane chociażby przez pryzmat doświadczeń młodych ludzi w zakresie edukacji, zatrudnienia, działań polityczno-społecznych dla nich dedykowanych oraz relacji i identyfikacji terytorialnej - są niezwykle ważne z punktu widzenia pokonywania kryzysów gospodarczych czy ograniczenia depopulacji obszarów wiejskich, widoczny jest zdecydowany deficyt tego typu badań w całej Unii Europejskiej (Jentsch i Schucksmith 2004; Machemer i in. 2008).

Stosunkowo szeroko dyskutowane są zagadnienia związane z zaangażowaniem młodzieży w rozwój społeczno-gospodarczy obszarów wiejskich (Roca de Nazaré Oliveira 1998; Gorlach i Foryś 2002; Corcoran 2003; Szafraniec 2005). W przypadku tych analiz młodzież wiejska jest traktowana jako potencjał (w tym potencjał obywatelski) w walce z różnymi ukrytymi rodzajami wykluczenia społecznego, jako swoisty bufor wszelkich

\footnotetext{
${ }^{3}$ We współczesnej geografii społeczno-ekonomicznej „refleksja” jest preferowanym terminem w odniesieniu do „wyjaśnienia”. Jedyna różnica w stosowaniu tych terminów polega na indywidualnym podejściu badacza do kwestii normatywności. Choć oba pojęcia konstruowane są ten sam sposób, jako że oba są wytworem ludzkiego umysłu, „refleksja” jest bardziej rzetelna, uczciwa w tym zakresie. „Wyjaśnienie” z kolei obarczone jest stygmatem traktowania nauki jako zdepersonalizowanej, wszechwiedzącej „wieży z kości słoniowej” trawionej przez predykcję, preskrypcję i kontrolę. Dlatego też coraz częściej w nauce odchodzi się od stosowania terminu „wyjaśnienie” na rzecz np. „refleksji” (Boyer 2015; Boström i in. 2017).

${ }^{4}$ Myśl ta pojawia się już w koncepcji K. Mannheim’a ogłoszonej w latach czterdziestych XX w. (Adamski 1980). K. Mannheim (1943) formułuje tezę, iż w młodzieży tkwi innowacyjny potencjał, który w momentach przełomowych - gdy przed społeczeństwem stoją wyzwania przeprowadzenia głębokich reform - można wykorzystać w procesach zmian jako czynnik dynamizujący strukturę społeczną. Młodzież stanowi więc pewną ukrytą rezerwę zmian będącą pochodną naturalnej skłonności młodych osób do kontestowania istniejącego porządku społecznego uznawanego przez dorosłych: rodziców i dziadków. Wyzwolenie tych potencjalnych sił młodego pokolenia zależy m.in. od charakteru danego społeczeństwa. Wykorzystaniu potencjału młodzieży sprzyja społeczeństwo dynamiczne, dążące do współpracy z młodzieżą, umożliwiające i wspierające integrację młodych osób, również poprzez partycypację w różnego rodzaju organizacjach i stowarzyszeniach (Mannheim 1928). Odmiennie kwestię tę postrzegał H.A. Giroux (2003), określając współczesną młodzież mianem „porzuconej generacji”. W książce, napisanej pod wpływem wydarzeń z 11 września 2001 r. i wpisującej się w krytyczny nurt socjologii zaangażowanej stwierdził on, że młode pokolenie zachodniej cywilizacji to nie tylko gen-X, e-generation, ale to przede wszystkim generacja zagrożona, opuszczona i pozbawiona w pewnym sensie przyszłości. Z jednej strony młodzież oskarżana jest tu o zbytnie wycofanie, konsumpcjonizm czy polityczną obojętność, ale z drugiej współczesne społeczeństwo obciąża młodych ludzi zbyt wielką odpowiedzialnością za jej własny los. To z kolei implikuje szereg ogromnych problemów w porównaniu z analogiczną sytuacją wcześniejszego pokolenia. W tym kontekście młodzież nie jest już częścią dyskursu lepszej przyszłości, ale raczej problemem społecznym. Jak wskazuje H.A. Giroux, w neoliberalnej gospodarce zasoby, których nie można wykorzystać - a tak można postrzegać kolejnych młodych, którzy nie mogą znaleźć pracy - są swego rodzaju balastem.
} 
działań społecznych. We współczesnej literaturze przedmiotu mamy do czynienia z licznymi publikacjami podejmującymi temat młodzieży wiejskiej (por. Bunting i Cousins 1985; McGrath 2001; de Gennaro i Fantini 2002; Vanderbeck i Morse Dunkley 2003; Rye 2006; Leyshon 2008; DeVoe i in. 2009; Shen i Shen 2014), przy czym zagadnienia badawcze są realizowane przede wszystkim w odniesieniu do tradycyjnie (stereotypowo?) pojmowanych obszarów wiejskich, np. jako obszary idylliczne, słabo zaludnione, peryferyjne czy po prostu obszary rolnicze. W badaniach nad młodzieżą wiejską pomijane są - lub w niewielkim stopniu eksponowane - obszary nietypowe. Jak słusznie zauważają A. Strzemińska i M. Wiśnicka (2011) termin „młodzież z obszarów wiejskich” stosowany jest w analizach jako określenie sugerujące homogeniczną kategorię, co nie jest w żaden sposób uprawnione. Z badań wspomnianych autorek wynika, że możliwe jest w tej kategorii wyodrębnienie szeregu podgrup, cechujących się znacznymi różnicami. Wszystko to decyduje o niewystarczającym zgłębieniu tematyki dotyczącej zasobów społecznych młodzieży wiejskiej. Do wspomnianych typów obszarów wiejskich z pewnością należą wsie popegeerowskie.

W związku z powyższym oraz niepodważalnym faktem, że wsie popegeerowskie uważane są za jedne z najbardziej problemowych w planowaniu rozwoju obszarów wiejskich, a zasoby społeczne jej dorosłych mieszkańców cechuje brak więzi, zaufania i gotowości do współpracy (szeroko dyskutowane m.in. w takich opracowaniach jak: Wilkin 1997; Tarkowska 2001; Karwacki 2002; Sakson 2003; Borowski 2013), w opracowaniu podjęto próbę odpowiedzi na pytania: (1) jakie są społeczne zasoby młodzieży mieszkającej w tego typu wsiach? (2) czy zasoby te różnią się od zasobów społecznych ich rodziców? i (3) czy zasoby te pozwalają upatrywać szansy na poprawę sytuacji wsi popegeerowskich w przyszłości? Podjęta analiza ma charakter prognostyczny, co jest szczególnie istotne w przypadku obszarów problemowych.

\section{Materiały i metody}

Wytypowany do badania obszar osiedla Chotel, przy zlikwidowanym formalnie w 1993 r. PGR, wpisuje się w opisany powyżej schemat przemian. To referencyjne osiedle, podobnie jak inne tego typu jednostki osadnicze, dotknął problem dynamicznego wzrostu liczby bezrobotnych. Brak odpowiedniego kapitału ludzkiego, niskie kwalifikacje, względnie niska mobilność mieszkańców (zwane też w literaturze przedmiotu syndromem wyuczonej bezradności; por. Tarkowska 2001; Karwacki 2002) spowodowały, że duża część mieszkańców osiedla bezskutecznie poszukuje pracy lub podejmuje tylko prace dorywcze (głównie sezonowe), stając się głównym beneficjentem pomocy socjalnej. Ponadto wraz z brakiem szans na dobrą pracę i malejącymi realnymi dochodami pogarszają się warunki życia mieszkańców, zaś bieda i wykluczenie społeczne staje się udziałem kolejnych pokoleń mieszkańców Chotla.

Z perspektywy badania zmian społecznych oraz poszukiwania przyczyn problemów rozwojowych istotną kwestią obserwowaną zarówno na badanym obszarze, jak i w innych osiedlach popegeerowskich jest kontynuacja (w nowych warunkach gospodarczych) zjawiska heterogeniczności. Procesy asymilacyjne mają tu bardzo ograniczony zakres: nadal istnieje podział mentalny na społeczność wsi i społeczność osiedla rolniczego, a rosnąca polaryzacja społeczna zdaje się ten podział pogłębiać. Wybrany do analizy Chotel szcze- 
gólnie mocno ukazuje ten problem, gdyż lokalizacja osiedla względem wsi Kazanki, której część formalnie stanowi, ma peryferyjny charakter, co dodatkowo utrudnia wzajemne kontakty i zwiększa izolację. Najbliższym miastem i jednocześnie siedzibą władz gminnych jest Izbica Kujawska (2770 mieszkańców), położona w odległości 3 km od badanego Chotla.

W 2014 r. populacja osiedla Chotel wynosiła około 120 osób (23\% osób w wieku przedprodukcyjnym, 64\% produkcyjnym i 13\% poprodukcyjnym). Obecnie osiedle stanowi miejsce zamieszkania przede wszystkim byłych pracowników PGR-u oraz ich rodzin, ale także - choć w mniejszym stopniu - nowych mieszkańców, którzy po roku 2000 otrzymali tu od Urzędu Gminy Izbica Kujawska przydział mieszkania socjalnego. Głównym źródłem utrzymania ludności w wieku produkcyjnym są prace dorywcze oraz zasiłki i świadczenia pomocowe. Prawie połowa z nich nie ma stałego miejsca pracy.

Opracowanie oparto przede wszystkim na danych pozyskanych w trakcie badania ankietowego. Badanie wykonano na nielosowej próbie (coraz częściej traktowanej jako ważna alternatywa badań probabilistycznych), gdyż niemożliwe okazało się dokładne oszacowanie wielkości populacji (część mieszkańców nie jest zameldowana). Próba nieprobabilistyczna oparta była na zasadzie dostępności. Formularz ankiety składał się przede wszystkim z zestawów pytań zamkniętych z przewagą skali szacunkowej (również w formie dyferencjału semantycznego), część pytań miała formę macierzy, zastosowano także metodę rangowania. Istotną rolę w kwestionariuszu odegrały też pytania otwarte, choć ich liczba była celowo ograniczona. W ten sposób badano tylko wybrane aspekty, m.in. zastosowano metodę skojarzeń swobodnych wykorzystywaną w badaniach wizerunku terytorium (Reilly 1990; Crouch i Ritchie 2003; Daszkiewicz 2012) do opisu osiedla oraz otoczenia społecznego.

Badaniu ankietowemu poddano 31 osób powyżej 15 roku życia (przy populacji wynoszącej ok. 120 osób), w tym 16 kobiet i 15 mężczyzn. Najważniejszą kategorią badawczą była tu młodzież, czyli osoby w przedziale wieku 15-19 lat. Na potrzeby oceny zasobów społecznych mieszkańców osiedla popegeerowskiego liczba respondentów reprezentujących kategorię młodzieży wynosiła 1/3 wszystkich badanych, tj. 10 osób. Wyniki badań ankietowych wśród młodzieży odniesiono następnie do wyników badań przeprowadzonych wśród osób dorosłych, głównie ich rodziców. Generalnie udało się przebadać przeciętnie co trzecią osobę powyżej 15 lat, co dało już dość dobry obraz sytuacji umożliwiający wyciąganie wniosków.

Zebrane dane uznano za wiarygodne i w pełni oddające stan wiedzy na temat badanego obszaru, co zweryfikowano w trakcie przeprowadzanych w ostatniej fazie badania wywiadów pogłębionych. Ten bardzo trudny etap podjęto po zakończeniu ankietyzacji, gdy respondenci zdążyli stopniowo oswoić się z sytuacją badania, a zebrany materiał wskazał, które kwestie wymagają pogłębienia. Niektóre zagadnienia poruszane w wywiadach wynikały bezpośrednio z kontekstu samej analizy i mogły być zbadane tylko metodą jakościową. Za optymalne rozwiązanie uznano wywiad swobodny. Badanie to prowadzono dzięki pomocy gatekeepera (który wprowadził autorów do badanej społeczności ze względu na jej hermetyczność), choć bez jego obecności. Łącznie przeprowadzono 7 wywiadów. Respondentów różnicowano pod kątem płci i wieku oraz aktywności zawodowej. Potwierdziły one wyniki uzyskane w drodze badań ankietowych i pozwoliły na głębsze zrozumienie pojawiających się kontekstów, których znajomość niezbędna była do przeprowadzenia właściwego wnioskowania. 


\section{Rezultaty}

Młodzież wiejska jest niezwykle ważną kategorią społeczną odgrywającą istotną rolę w pobudzaniu rozwoju społeczno-gospodarczego obszarów wiejskich. Kreuje kapitał ludzki i zasoby społeczne wsi, które z kolei decydują o tempie i zakresie zmian społeczno-gospodarczych zachodzących na obszarach wiejskich (Krzyminiewska 2009).

Starając się znaleźć odpowiedź na pytania postawione w niniejszym opracowaniu, a związane z lokalnymi zasobami społecznymi młodzieży mieszkającej we wsiach popegeerowskich, należy zwrócić uwagę na jeden z zasadniczych czynników wzrostu konkurencyjności obszarów wiejskich, a mianowicie wiedzę (Bański 2013; Müller-Frączek i Muszyńska 2015). Determinowana jest ona sukcesywnie wzrastającym poziomem wykształcenia w Polsce, w tym również na obszarach wiejskich. Generalnie przyjmuje się, że inwestycje, które mają na celu podwyższanie wykształcenia społeczeństwa, traktowane są we współczesnym świecie na równi z inwestycjami gospodarczymi. Zwracają na to uwagę w zasadzie wszystkie teorie rozwoju społecznego. Problemy takie jak: ubóstwo, bezrobocie, marginalizacja czy izolacja społeczna mogą być rozwiązane tylko wtedy, kiedy zmianie na lepsze ulegną zasoby intelektualne społeczeństwa (Maślanka 2008). Wysoki poziom wykształcenia powoduje wzrost postaw prorynkowych i liberalnych, pozwala się lepiej odnaleźć w świecie podlegającym procesowi globalizacji i zdominowanym przez ostrą konkurencję, sprzyja tworzeniu miejsc pracy w sektorze usługowym oraz przyspiesza przemiany zmierzające ku rozwojowi wielofunkcyjnemu wsi. Niski poziom wykształcenia z kolei ogranicza szeroko rozumiany rozwój, powoduje utrwalanie postaw zachowawczych wśród społeczeństwa oraz ogranicza szanse awansu społecznego (Szymczak 2005).

Wśród badanej młodzieży dokładnie połowa posiadała wykształcenie podstawowe, a 1/3 zasadnicze zawodowe. Co jest jednak szczególnie ważne, ponad 3/4 respondentów w przedziale wieku 15-19 lat zadeklarowała, że zamierzała się dalej kształcić. Jest to sytuacja różna od tej obserwowanej w kategorii osób dorosłych. Tutaj 1 na 10 badanych osób zadeklarowała wykształcenie podstawowe, a 3/4 zasadnicze zawodowe. Dalsze plany edukacyjne miała $1 / 3$ badanych, natomiast 1 na 10 respondentów wahała się i wybrała opcję "trudno powiedzieć" (tab. 1). Pomimo napawających pewnym optymizmem deklaracji, zauważyć należy, że struktura wykształcenia mieszkańców analizowanego osiedla popegeerowskiego różni się od struktury, która notowana jest na obszarach wiejskich w Polsce (por. Rocznik demograficzny 2013). Przede wszystkim brakuje tu osób z wykształceniem wyższym (dla porównania na obszarach wiejskich w Polsce udział osób z wykształceniem wyższym wynosi 9,9\%, stan na 2011 r.), niski jest także udział osób z wykształceniem średnim (na obszarach wiejskich w Polsce - 25\%). Mało korzystna struktura wykształcenia wśród osób dorosłych może poprzez kapitał kulturowy niekorzystnie ukierunkowywać postawy i zachowania młodzieży, a tym samym przyszłe lokalne zasoby społeczne wsi.

W literaturze przedmiotu same lokalne zasoby społeczne mieszkańców obszarów wiejskich ocenia się głównie poprzez pryzmat relacji, gotowości do współpracy i poziomu zaufania (por. Fedyszak-Radziejowska 2006a). Podobne zagadnienia przeanalizowano w niniejszym opracowaniu w odniesieniu do młodzieży, a następnie do osób dorosłych.

Starając się ustalić relacje panujące na badanym osiedlu popegeerowskim zapytano, czy ankietowani lubią swoich sąsiadów. Na tak postawione pytanie zdecydowana 
większość młodych ludzi z Chotla odpowiedziała „tak” lub „zdecydowanie tak” (tab. 2). Generalnie młodzież postrzega swoich sąsiadów jako osoby pomocne, sympatyczne i rozmowne. Z kolei odnosząc się do gotowości młodych osób do podejmowania współpracy, należy zaznaczyć, że cenią sobie oni przede wszystkim kontakty z sąsiadami. Chętnie (ponad 1/3 wskazań) widzą ich jako gości w swoich domach. Ponadto co trzecia młoda osoba zadeklarowała, że gdyby potrzebowała pomocy, to zwróciłaby się właśnie do sąsiadów (tab. 4). Temu dalece pozytywnemu obrazowi nieco przeczy fakt, że młodzież z badanego osiedla wśród wielu osób, z którymi ma kontakt, zaufaniem obdarza jednak głównie członków rodziny, przyjaciół i sympatie (niekoniecznie z osiedla) (tab. 3). Co więcej, w sytuacjach problemowych, gdy pojawiają się kłopoty, prawie połowa populacji badanej młodzieży deklaruje, że szuka pomocy u osób spoza Chotla. Te silne relacje pozarodzinne młodych osób znajdują potwierdzenie nie tyko w sytuacjach kryzysowych, stresogennych, ale także w momentach związanych z wypoczynkiem. Blisko 3/4 z nich podkreśla, że czas wolny spędza właśnie ze znajomymi spoza osiedla. Ponadto ponad połowa z nich jest przekonana, że ci znajomi przejmują się ich losem i warunkami życia. Interesujący jest jednak fakt, że na pytanie: „Do kogo Pan/i się zwraca z prośbą o pomoc, kiedy jest Pan/i w potrzebie? " najwięcej, bo aż 3/4 młodych respondentów przyznaje, że jednak do rodziny (tab. 4).

Tabela 1. Struktura wykształcenia i plany edukacyjne młodzieży i dorosłych mieszkańców terenów popegeerowskich

\begin{tabular}{|l|c|c|}
\hline \multicolumn{1}{|c|}{ Poziom wykształcenia } & Młodzież (\%) & Dorośli (\%) \\
\hline podstawowe & 50,0 & 10,5 \\
zasadnicze zawodowe & 37,5 & 73,7 \\
średnie & 12,5 & 15,8 \\
\hline \multicolumn{2}{|c|}{ Czy zamierza się Pan/i jeszcze kształcić? } \\
\hline tak & 77,8 & 30,0 \\
trudno powiedzieć & 22,2 & 15,0 \\
nie & 0,0 & 55,0 \\
\hline
\end{tabular}

Źródło: opracowanie własne na podstawie wyników badania ankietowego.

Tabela 2. Struktura odpowiedzi udzielonych przez młodzież i dorosłych mieszkańców terenów popegeerowskich na pytanie: Czy lubi Pan/i swoich sąsiadów?

\begin{tabular}{|l|c|c|}
\hline \multicolumn{1}{|c|}{ Odpowiedzi: } & Młodzież (\%) & Dorośli (\%) \\
\hline zdecydowanie tak & 30,0 & 0,0 \\
tak & 40,0 & 42,1 \\
trudno powiedzieć & 10,0 & 31,6 \\
nie & 10,0 & 15,8 \\
zdecydowanie nie & 10,0 & 10,5 \\
\hline
\end{tabular}

Źródło: opracowanie własne na podstawie wyników badania ankietowego. 
Tabela 3. Struktura odpowiedzi udzielonych przez młodzież i dorosłych mieszkańców terenów popegeerowskich na pytanie: Największe zaufanie ma Pan/i do:..?

\begin{tabular}{|l|cc|cc|}
\hline \multirow{2}{*}{ Odpowiedzi: } & \multicolumn{2}{|c|}{ Młodzież (\%) } & \multicolumn{2}{c|}{ Dorośli (\%) } \\
\cline { 2 - 4 } & TAK & NIE & TAK & NIE \\
\hline ojca & 11,1 & 88,9 & 19,0 & 81,0 \\
matki & 22,2 & 77,8 & 28,6 & 71,4 \\
męża/żony & 0,0 & 100,0 & 19,0 & 81,0 \\
brata/siostry & 11,1 & 88,9 & 28,6 & 71,4 \\
członka rodziny & 11,1 & 88,9 & 4,8 & 95,2 \\
przyjaciela & 55,6 & 44,4 & 9,5 & 85,7 \\
dziecka & 0,0 & 100,0 & 14,3 & 100,0 \\
kochanka/i & 0,0 & 100,0 & 0,0 & 100,0 \\
nauczyciela & 0,0 & 100,0 & 0,0 & 85,7 \\
chłopaka/dziewczyny & 22,2 & 77,8 & 14,3 & 90,5 \\
sąsiada & 11,1 & 88,9 & 9,5 & 100,0 \\
księdza & 11,1 & 88,9 & 0,0 & \\
\hline
\end{tabular}

Źródło: opracowanie własne na podstawie wyników badania ankietowego.

Tabela 4. Struktura odpowiedzi udzielonych przez młodzież i dorosłych mieszkańców terenów popegeerowskich na pytanie: Do kogo Pan/i się zwraca z prośbą o pomoc, kiedy jest Pan/i w potrzebie, do...?

\begin{tabular}{|c|c|c|c|c|}
\hline \multirow{2}{*}{ Odpowiedzi: } & \multicolumn{2}{|c|}{ Młodzież (\%) } & \multicolumn{2}{|c|}{ Dorośli (\%) } \\
\hline & TAK & NIE & TAK & NIE \\
\hline rodziny & 70,0 & 30,0 & 85,7 & 14,3 \\
\hline sąsiadów & 30,0 & 70,0 & 14,3 & 85,7 \\
\hline mieszkańców osiedla & 0,0 & 100,0 & 0,0 & 100,0 \\
\hline mieszkańców sąsiednich wsi/osiedla & 10,0 & 90,0 & 0,0 & 100,0 \\
\hline GOPS* & 10,0 & 90,0 & 4,8 & 95,2 \\
\hline instytucji na szczeblu powiatu & 0,0 & 100,0 & 0,0 & 100,0 \\
\hline instytucji na szczeblu województwa & 0,0 & 100,0 & 0,0 & 100,0 \\
\hline instytucji na szczeblu państwowym & 0,0 & 100,0 & 0,0 & 100,0 \\
\hline instytucji Unii Europejskiej & 0,0 & 100,0 & 0,0 & 100,0 \\
\hline fundacji & 0,0 & 100,0 & 0,0 & 100,0 \\
\hline Kościoła & 10,0 & 90,0 & 0,0 & 100,0 \\
\hline szkoły & 0,0 & 100,0 & 0,0 & 100,0 \\
\hline
\end{tabular}

Objaśnienie: GOPS - Gminny Ośrodek Pomocy Społecznej

Źródło: opracowanie własne na podstawie wyników badania ankietowego.

O jakości społecznych zasobów młodzieży wiejskiej decydują także postawy, poglądy i przekonania ich rodziców. W przypadku dorosłych mieszkańców osiedli popegeerowskich na pierwszy plan wysuwa się deficyt zaufania, brak gotowości do współpracy i alienacja, a zatem postawy hamujące wykorzystanie szans rozwojowych zdegradowanych obszarów wiejskich (Kwiecińska-Zdrenka 2004). Wobec powyższego, aby w pełni zobrazować zna- 
czenie społecznych zasobów młodzieży ze wsi popegeerowskich w pobudzaniu rozwoju społeczno-gospodarczego tych obszarów, prześledzono także zasoby społeczne, którymi dysponowali dorośli mieszkańcy analizowanego osiedla, czyli ich rodzice i dziadkowie. Jak wynika z badań, dorośli są najbardziej związani z tymi, których najlepiej znają, a więc głównie z najbliższą rodziną. Czas wolny spędzają także przede wszystkim w gronie rodzinnym (prawie $3 / 4$ ogółu badanych). Wszyscy badani dorośli podkreślili, że nikt lub prawie nikt nie przejmuje się ich losem, a jeżeli już, to jest to właśnie rodzina (ponad 3/4) i podobnie jak ich dzieci, u członków rodziny szukają głównie pomocy (tab. 4). Stąd też osoby dorosłe największym zaufaniem obdarzają członków najbliższej rodziny, tj. matkę i rodzeństwo, a następnie: współmałżonka i ojca. Aczkolwiek, tak jak w przypadku młodzieży, symptomatyczny jest niezwykle wysoki poziom nieufności do innych osób (np. sąsiadów, przyjaciół, księży, nauczycieli) i przedstawicieli instytucji (tab. 3). Ponadto dorosłych cechuje brak otwartości w stosunku do mieszkańców osiedla, co przejawia się na przykład w tym, że wśród zapraszanych do domu gości niespełna 10\% stanowią osoby z tej samej wsi. Należy też dodać, że wśród generalnych opinii na temat osób z najbliższego otoczenia dominują pejoratywne określenia takie, jak: „parszywe”, „plotkarskie”, „kłótliwe” i „wrogo nastawione". Dlatego też nie dziwi fakt, że tylko nieliczni dorośli respondenci wskazali sąsiadów jako tych, do których gotowi są zwrócić się z prośbą o pomoc, nikt nie wskazał mieszkańca osiedla oraz mieszkańców sąsiednich wsi (tab. 4).

Preferowanie członków rodziny i brak zaufania do innych osób i instytucji, nawet tych cieszących się powszechnym zaufaniem społecznym (np. żaden badany dorosły nie wskazał księdza, jako osoby godnej zaufania) deklarowane przez dorosłą część mieszkańców osiedla popegeerowskiego są wyrazem szerszego trendu określanego mianem kapitału przetrwania i adaptacji. Takie wzorce zachowań były typowe dla okresu socjalizmu. We wsiach popegeerowskich występują jednak współcześnie i co gorsze, są powielane przez młodsze pokolenia, a nawet ulegają wzmocnieniu (Polska 2030 2009). Odtwarzanie zachowań i postaw dorosłych przez kolejne pokolenie mieszkańców wsi popegeerowskich jest szczególnie widoczne w deficycie zaufania do innych osób i wszelkich instytucji publicznych. Młodzież i osoby dorosłe (ich rodzice) jednomyślnie stwierdzają, że zarówno instytucje gminne (nawet te, w gestii których leży pomoc socjalna), powiatowe, regionalne, wojewódzkie, a także międzynarodowe (np. z ramienia Unii Europejskiej) oraz przedstawiciele fundacji czy instytucji kościelnych nie przejmują się losem i warunkami ich życia. Na pytanie: „Jak ocenia Pan/i pomoc instytucji w zakresie pomocy Pana/i rodzinie? " zarówno młodzież, jak i dorośli, odpowiadali zwykle wymijająco: „nie dotyczy mnie". Punktem stycznym poglądów młodzieży i dorosłych z obszarów popegeerowskich jest także powszechne przekonanie, że mieszkańcy wsi nie martwią się o siebie nawzajem. Potwierdzają to także odpowiedzi udzielone na pytanie: „Do kogo Pan/i się zwraca z prośbą o pomoc, kiedy jest Pan/i w potrzebie? ". Wśród wskazań brak mieszkańców osiedla, natomiast sąsiadów wymieniają tylko nieliczne osoby dorosłe i reprezentanci młodzieży (tab. 4), choć w większości obie badane kategorie twierdzą, że wszyscy mieszkańcy wsi się znają. Jednak znać kogoś, nie oznacza być z nim zżytym. Aż 4 na 10 osób młodych i tyle samo dorosłych odpowiadając na pytanie o to, czy mieszkańcy Chotla są ze sobą zżyci, wskazało odpowiedź „trudno powiedzieć”. Kolejna 1/5 młodzieży i ponad 1/3 ankietowanych dorosłych odpowiedziało „nie”, a nawet „zdecydowanie nie”. Niedostatku więzi sąsiedzkich należy upatrywać w postawach i przekonaniach samych mieszkańców. Pytani o przyczyny braku porozumienia i przyjacielskich relacji dorośli wymieniali trzy główne 
motywy: „każdy żyje swoim życiem”, „istnieje podział na grupy” i „zazdrość”. W przypadku oceny dokonywanej przez młodzież również dominuje przekonanie o antagonizmach, ale prócz odpowiedzi o ogólnym odgradzaniu się od innych („same płoty”), udzielono także odpowiedzi: „niektórzy są zżyci, inni nie, istnieje podział na grupy”. I właśnie wychwycenie przez młodych możliwości istnienia relacji sąsiedzkich odróżnia ich od dorosłych.

Rozważając z kolei pytanie o to, czy społeczne zasoby młodzieży pozwalają upatrywać szansy na poprawę sytuacji wsi popegeerowskich w przyszłości, należy mieć na uwadze fakt, że pomimo istotnych podobieństw z zasobami społecznymi prezentowanymi przez starsze pokolenie, więzi kształtowane przez młode osoby wykraczają poza krąg rodzinny i w pewnym zakresie obejmują także sąsiadów - mieszkańców tej samej wsi. Wyjście poza relacje typowo rodzinne i dostrzeżenie szans nawiązania bliższych relacji z sąsiadami może stanowić symptom aktywizacji młodych ludzi. Zapowiedzią tego ożywienia jest także fakt, że zdecydowana większość młodych osób pragnie zwiększać swoje kompetencje i poszerzać zakres wiedzy i umiejętności, co w znacznym stopniu determinuje jakość społecznych zasobów młodzieży wiejskiej.

\section{Dyskusja}

Omówione powyżej wyniki badań tylko z pozoru stanowią przegląd postaw i zachowań młodych ludzi żyjących w specyficznym środowisku ukształtowanym po upadku PGR. Faktyczny zakres analizy ma znacznie głębszy wymiar, gdyż wszelkie spostrzeżenia dotyczące tej grupy społecznej traktowane są jako prognostyk, pozwalający przewidzieć przyszłą sytuację tych trudnych obszarów wiejskich.

Wnioskowanie tego typu jest w oczywisty sposób traktowane przez autorów bardzo ostrożnie. Wynika to z kilku przesłanek, o których warto wspomnieć. Po pierwsze, nie wiemy, jakie będą przyszłe potrzeby i w związku z tym nie jesteśmy w stanie wskazać, czy stwierdzone zasoby zostaną uruchomione i staną się kapitałem społecznym. Odpowiedzi na te pytania należy szukać w kierunku i sposobie prowadzenia polityki na szczeblu lokalnym, ale również w charakterze polityki państwa wobec jednostek terytorialnych najniższego szczebla, czy w kierunku działań podejmowanych przy rozwiązywaniu problemów rozwojowych w obszarach trudnych, często dysfunkcjonalnych i dereliktowych, jak w rozważanym studium przypadku. Po drugie, nie możemy przewidzieć ewolucji tych zasobów. Obecne postawy młodzieży, jak otwartość, gotowość do współpracy, zaufanie będą wraz z wiekiem i nabytym doświadczeniem życiowym ulegać modyfikacjom. Określenie, jak dalece ulegną odkształceniom i w jakim kierunku, jest skazane na niepowodzenie. Po trzecie, nie sposób uwzględnić przy przewidywaniach wielu zmiennych, które będą kształtowały przyszły stan gospodarki państwa, regionu czy świata, decydując o jej stabilności, a tym samym wpływając na rozwój lokalny, potrzeby mieszkańców itp.

Ważnym aspektem podjętego tematu jest sposób konstruowania polityki społecznej w odniesieniu do PGR-ów na poziomie konceptualnym. Problemy społeczne nierozerwalnie związane z obszarami formalnie wiejskimi zwykle charakteryzowane są przez ograniczony dostęp do środków transportu, bardziej niekorzystne struktury demograficzne (w tym większe zróżnicowanie wieku i płci mieszkańców), określone systemy dziedziczenia lub specyficzne formy mieszkalnictwa (European Commission 2008). Jednak gdy polityka społeczna rozpatruje deprywację według formalnego podziału na wieś 
i miasto, to może ona oznaczać w każdym z tych kontekstów coś innego (por. Shortall 2008). A. Karwacki (2002, s. 90) ujął to nieco inaczej: „Uniwersalizm kultury ubóstwa [...] nie stanowi typu idealnego, jest raczej lokalnie zmodyfikowanym jądrem tej kultury, która żyje własnym życiem". Zatem pomimo tego, że nie brakuje studiów badających relacje pomiędzy „wiejską polityką społeczną" a deprywacją (por. Woolcock i Narayan 2000; Bryant i Pini 2011; Delbosc i Curry 2011; Lucas 2012; Levy i Shady 2013), globalną tendencją wśród publikowanych wyników badań naukowych jest utrzymująca się "lokalizacja” problemów w prototypowo pojmowanych obszarach wiejskich (Philo 1992; Little 1999; Woodward 1996; Philip i Shucksmith 2003). Rozpatrując kwestie związane z polityką społeczną, warto dodać, że po pierwsze - miejsca daleko przekraczające typowe charakteryzacje wiejskie są często pomijane w tej polityce (np. osiedla mieszkaniowe odcięte od nowoczesnej infrastruktury i usługowienia, wsie typu brownfield, flophousy, parki z przyczepami mieszkalnymi, shantytowny, favele, miasteczka namiotowe, a nawet byłe kołchozy i sowchozy). Po drugie - koncepcyjne braki polityki społecznej mogą tłumić odpowiedniki „problemów miejskich” w obszarach formalnie wiejskich i vice versa (Levy 2010). Taka praktyka kategoryzacji może nieść ze sobą niebezpieczeństwo utożsamiania ludzi z charakterystyką przestrzeni fizycznej (Dymitrow i Brauer 2016), równocześnie zubażając przestrzeń społeczną poprzez niedostrzeganie lub bagatelizowanie różnic między różnymi rodzajami wiejskości (Sibley 1988). W kontekście PGR-ów, problem ten może mieć wpływ zarówno na jakość, jak i na ilość podjętych interwencji. Może także wpływać na to, jak kreowani są młodsi mieszkańcy osiedli popegeerowskich oraz - w konsekwencji - jak są konceptualizowani jako potencjalne zasoby (np. jak twierdzi R. Marks-Bielska 2005, s. 11, „rzeczywiste możliwości edukacyjne dzieci i młodzieży ze środowisk popegeerowskich są bardzo ograniczone, szczególnie z uwagi na brak środków finansowych na ten cel"; por. też Marks-Bielska 2002).

Mając pełną świadomość złożoności zagadnienia i trudności, które ujawniają się we wszystkich ujęciach perspektywicznych, próba refleksji nad aktualnymi zasobami społecznymi reprezentowanymi przez młodzież, a tym samym nad potencjalnymi zasobami osiedli popegeerowskich, może stać się cenną wskazówką, jak dziś odnieść się do tych zasobów, by zdiagnozować właściwie problem i stymulować ich rozwój we właściwym kierunku. Uzyskane wyniki należy zatem traktować nie w kategorii prognozy najbardziej prawdopodobnej, lecz raczej jako wariant prognozy ostrzegawczej. To bardzo istotne, zwłaszcza gdy zastanawiając się nad szansą przekształcenia tych zasobów w kapitał społeczny, musimy mieć na uwadze, że skuteczna polityka to taka, która jest właściwie osadzona. Jej fundamentem są właśnie społeczne zasoby lokalne. Ich optymalne wykorzystanie, zwłaszcza na obszarach problemowych, jest koniecznością. Aby podejmowane działania okazały się skuteczne, należy dostrzec tkwiące tu zarówno zagrożenia, jak i szanse.

W opracowaniu zwrócono w pierwszej kolejności uwagę na stan zasobów społecznych reprezentowanych przez młodzież wsi popegeerowskiej. Za zagrożenie należy uznać słabość więzi społecznych w ramach społeczności lokalnej manifestującą się brakiem zaufania zarówno do sąsiadów i mieszkańców wsi (choć wszyscy się znają), jak i do wszelkich instytucji. Uderza fakt, że prawie połowa młodych ludzi w sytuacjach problemowych nie znajduje wsparcia wśród osób z najbliższego otoczenia, a szuka jej poza Chotlem. Wskazuje to na problem deficytu w tym zakresie, który rekompensowany jest poza społecznością lokalną (być może mniej obciążoną własnymi problemami, lepiej radzącą sobie z ich rozwiązywaniem). Wszyscy młodzi badani i bez mała wszyscy dorośli uważają, że mieszkańcy 
wsi nie troszczą się o siebie nawzajem. Tak jednoznaczne deklaracje świadczą o poważnym braku spójności społecznej w grupie, co wynika z jej heterogeniczności. Niepokojące jest także i to, że opinie młodzieży wskazują na utrwalenie tej cechy.

Z kolei jako szansa rozwojowa rysuje się dostrzeżony pozytywny stosunek młodzieży do osób z bliskiego otoczenia. Zdecydowana większość spośród nich deklaruje, że lubi swoich sąsiadów. Z pozoru może być to postrzegane jako pewna niekonsekwencja wobec wskazanego wyżej problemu słabej spójności. Należy jednak spojrzeć na tę kwestię jako pewien symptom przyszłych zmian. Choć zaledwie co dziesiąty młody mieszkaniec wsi uważa, że mieszkańcy są ze sobą zżyci, to pozytywny stosunek do osób z bliskiego otoczenia może dopiero z czasem przerodzić się w akceptację, wzajemne zainteresowanie problemami otoczenia.

Warto podkreślić, że zasoby określone dla młodzieży różnią się od zasobów zidentyfikowanych dla dorosłych mieszkańców wsi. Szukając pewnych prawidłowości, można najogólniej wskazać, że w aspektach uznanych wyżej za zagrożenia dla rozwoju osiedla poglądy osób młodych i pozostałych członków społeczności są dość zbliżone, natomiast w kategorii szans rysują się istotniejsze różnice na korzyść osób młodych.

Z perspektywy pogłębionej wiedzy na temat zasobów społecznych młodzieży trudno o jednoznaczne wskazanie, czy badany element wpłynie pozytywnie czy negatywnie na rozwój rozważanego obszaru. Wydaje się, że nie ma jednoznacznej odpowiedzi na to pytanie, zwłaszcza że do tego typu oceny zawsze potrzebny jest szerszy kontekst. Jednak poczynione ustalenia w zupełności wystarczą, by wskazać problem, który dziś rysuje się jako dziedziczony brak zainteresowania wobec członków społeczności lokalnej, oraz by dostrzec szansę, za którą można uznać przyjazne nastawienie młodych ludzi do otoczenia. Choć nie podąża za nim zaufanie, może przerodzić się w zrozumienie, że mieszkańcy wsi są sobie nawzajem potrzebni.

\section{Literatura}

Adamski W., 1980, Młodzież w społeczeństwie, konfrontacje polsko-amerykańskie, Wydawnictwo Książka i Wiedza, Warszawa.

Bański J., 2002, Typy ludnościowych obszarów problemowych, Studia Obszarów Wiejskich, 2, s. 41-52.

Bański J., 2007, Geografia rolnictwa Polski, PWE, Warszawa.

Bański J., 2013, O przyszłości polskiej wsi, Studia Obszarów Wiejskich, 31, s. 9-24.

Będzik B., 2008, Bariery i możliwości generowania kapitału społecznego na obszarach wiejskich w Polsce, Acta Scientorum Polonorum, Oeconomia, 7 (4), s. 27-34.

Biegańska J., 2013, Rural areas in Poland from a demographic perspective, Bulletin of Geography. Socio-economic Series, 20, s. 7-22. DOI: 10.2478/bog-2013-0008

Biegańska J., Szymańska D., 2013, The scale and the dynamics of permanent migration in rural and peri-urban areas in Poland - some problems, Bulletin of Geography. Socio-economic Series, 21, s. 21-30. DOI: http://dx.doi.org/10.2478/bog-2013-0017

Biegańska J., Dymitrow M., Grzelak-Kostulska E., Środa-Murawska S., 2017, From Policy to Misery: The State Agricultural Farm vs. 'the Rural' (w przygotowaniu).

Borowski A., 2013, Cooperative and national agricultural farm as total institutions, International Letters of Social and Humanistic Sciences, 11, s. 100-105. 
Boström M., Lidskog R., Uggla Y., 2017, A reflexive look at reflexivity in environmental sociology, Environmental Sociology, 3, 1, s. 6-16.

Boyer D., 2015, Reflexivity reloaded: from anthropology of intellectuals to critique of the method to studying sideways. Anthropology now and next: essays in honor of Ulf Hannerz, Berghahn, New York.

Bryant L., Pini B., 2011, Gender and rurality, Routledge, New York.

Bunting T.E., Cousins L.R., 1985, Environmental dispositions among school-age children: A preliminary investigation, Environment and Behavior, 17 (6), s. 725-768.

Churski P., Perdał R., 2008, Czynniki rozwoju społeczno-gospodarczego w układzie regionalnym Unii Europejskiej, [w:] S. Dołzbłasz, A. Raczyk (red.), Przekształcenia regionalnych struktur funkcjonalno-przestrzennych. Europa bez granic - nowa jakość przestrzeni, Rozprawy Naukowe Instytutu Geografii i Rozwoju Regionalnego Uniwersytetu Wrocławskiego, 4, s. 21-32.

Corcoran C., 2003, Partnership, Exclusion and the Young: The Neglected Voice of the Rural Young, [w:] K.B. Beesley, H. Millward, B. Ilbery, L. Harrington, (red.), The New Countryside: Geographic Perspectives on Rural Change, Brandon University and Saint Mary's University, Brandon-Halifax, s. 351-364.

Crouch G.I., Ritchie J.R.B., 2003, The competitive destination, CABI Publishing, Cambridge.

Daszkiewicz M., 2012, Research on the territorial image using methods based on free association, [w:] K. Mazurek-Łopacińska (red.), Nauki o Zarzqdzaniu, WUE, Wrocław, s. 74-83.

Delbosc A., Currie G., 2011, The spatial context of transport disadvantage, social exclusion and well-being, Journal of Transport Geography, 19 (6), s. 1130-1137.

DeVoe J.E., Krois L., Stenger R., 2009. Do children in rural areas still have different access to health care? Results from a statewide survey of Oregon's food stamp population, The Journal of Rural Health, 25 (1), s. 1-7.

Dymitrow M., Biegańska J., Grzelak-Kostulska E., 2017, Deprivation and the rural-urban trap, Tijdschrift voor economische en sociale geografie. DOI: http://dx.doi.org/10.1111/tesg.12263 (w druku).

Dymitrow M., Brauer R., 2016, Land or People? On the latrogenesis of conflation, Acta Geobalcanica, 2 (2), s. 63-75.

European Commission, 2008, Poverty and social exclusion in rural areas, Directorate-General for Employment, Social Affairs and Equal Opportunities, Brussels.

Fedyszak-Radziejowska B., 2006a, Czy kapitał społeczny bez społecznego zaufania jest możliwy? [w:] K. Szafraniec (red.), Jednostkowe i społeczne zasoby wsi, IRWiR PAN, Warszawa, s. $123-146$.

Fedyszak-Radziejowska B., 2006b, Kapitał społeczny wsi - w poszukiwaniu utraconego zaufania, [w:] K. Szafraniec (red.), Kapitał ludzki i zasoby społeczne wsi. Ludzie-społeczność lokaIna-edukacja, IRWiR PAN, Warszawa, s. 71-120.

Feltynowski M., Senetra A., Biegańska J., Grzelak-Kostulska E., Dymitrow M., Środa-Murawska S., 2015, Some problems of local development: the example of former State Agricultural Farms in Poland, Research for rural development 2015, annual 21th International Scientific Conference, proceedings, 2, Latvia University of Agriculture, Jelgava, s. 237-243.

Forbrig J. (red.), 2005, Revisiting youth political participation: Challenges for research and democratic practice in Europe, Council of Europe, Strasbourg.

de Gennaro B., Fantini A., 2002, The concept of rurality and the rural-urban relationship as perceived by young people. [w:] A. Cristovao, L. Omodei Zorini (red.), Farming and rural systems research and extension, ARSIA, Florence, s. 253-263. 
Giroux H.A., 2003, The abandoned generation. Democracy beyond the culture of fear, Palgrave MacMillan, New York.

Giza-Poleszczuk A., Marody M., Rychard A., 2000, Strategie i system. Polacy w obliczu zmiany społecznej, IFiS PAN, Warszawa.

Gorlach K., Foryś G., 2003, Key issues in rural-urban relations in Poland: between present past and European future, [w:] A. Cristovao, L. Omodei Zorini (red.), Farming and rural systems research and extension, Florence, ARSIA, s. 289-298.

Halamska M., 2008, Kapitał społeczny wsi: próba rekonstrukcji, Przegląd Socjologiczny, 57, 1, s. 81-104.

Jentsch B., Shucksmith M., (red.), 2004, Young People in Rural Areas of Europe, Ashgate, Aldershot.

Kallio K.P., 2016, Youthful political presence: Right, reality and practice of the child, [w:] K.P. Kallio, S. Mills (red.), Politics, Citizenship and Rights, Springer, Singapore, s. 89-110.

Karwacki A., 2002, The Culture of Poverty in the Post-State Farm Community, Eastern European Countryside, 8, s. 79-93.

Kosmaczewska J., 2009, Kapitał społeczny mieszkańców wsi jako czynnik turystycznego rozwoju obszarów wiejskich, Acta Scientorum Polonorum. Oeconomia, 8 (4), s. 87-96.

Kożuch A., 2011, Rola samorzadu terytorialnego we wspieraniu rozwoju lokalnego, [w:] A. Kożuch, A. Noworól (red.), Instrumenty zarzq̨dzania rozwojem w przedsiębiorczych gminach, Instytut Spraw Publicznych Uniwersytetu Jagiellońskiego, Kraków, s. 9-17.

Kraciński P., 2011, The disposition of agricultural property of the National Treasury 1992-2009, Ekonomika Organizacja Gospodarki Żywnościowej, 87, s. 41-53.

Krzyminiewska G., 2009, Wiedza ekonomiczna i umiejętności społeczne młodzieży wiejskiej, Acta Scientarium Polonorum. Oeconomia, 8 (3), s. 57-67.

Krzysztofik R., Dymitrow M., Grzelak-Kostulska E., Biegańska J., 2017, Poverty and social exclusion: An alternative spatial explanation, Bulletin of Geography. Socio-economic Series, 35, s. 45-64. DOI: http://dx.doi.org/10.1515/bog-2017-0004

Kwiecińska-Zdrenka M., 2004, Aktywni czy bezradni wobec własnej przyszłości?, Uniwersytet Mikołaja Kopernika, Toruń.

Levy S., 2010, Good intentions, bad outcomes: Social policy, informality, and economic growth in Mexico, Brookings Institution Press, Washington.

Levy S., Schady N., 2013, Latin America's social policy challenge: education, social insurance, redistribution, Journal of Economic Perspectives, 27 (2), s. 193-218.

Leyshon M., 2008, The betweenness of being a rural youth: inclusive and exclusive lifestyles, Social \& cultural geography, 9 (1), s. 1-26.

Little J., 1999, Otherness, Representation and the Cultural Construction of Rurality, Progress in Human Geography, 23 (3), s. 437-442.

Lucas K., 2012, Transport and social exclusion: Where are we now?, Transport Policy, 20, s. 105-113.

Machemer P.L., Bruch S.P., Kuipers R., 2008, Comparing rural and urban children's perceptions of an ideal community, Journal of Planning Education and Research, 28 (2), s. 143-160.

Mannheim K., 1928, Das Problem der Generationen, Kölner Vierteljahrshefte für Soziologie, 7 , s 157-185, 309-330.

Mannheim K., 1943, Diagnosis of our Times. Wartime Essays of a Sociologist, Chapter III: The Problem of Youth in Modern Society, Kegan Paul, Trench, Trubner \& CO., LTD, London.

Marks-Bielska R., 2002, Edukacja szansq awansu społecznego młodzieży ze środowisk popegeerowskich, Polityka Społeczna, 10, s. 17-20.

Marks-Bielska R., 2005, Byli pracownicy PGR jako „przegrani” transformacji ustrojowej popegeerowskich, Polityka Społeczna, 7, s. 9-12. 
Maślanka J., 2008, Uwarunkowania dostępu do lokalnych rynków pracy mieszkańców obszarów wiejskich Kujaw, [w:] K. Heffner (red.), Współczesne problemy rozwoju ośrodków lokalnych, Akademia Ekonomiczna, Katowice, s. 71-85.

McGrath B., 2001, "A problem of resources": defining rural youth encounters in education, work \& housing, Journal of Rural Studies, 17 (4), s. 481-495.

Müller-Frączek I., Muszyńska J., 2015, Kapitał intelektualny polskiej wsi a poziom życia jej mieszkańców, Stowarzyszenie Ekonomistów Rolnictwa i Agrobiznesu, Roczniki Naukowe, 17, 6, s. 198-203.

Philip L.J., Shucksmith M., 2003, Conceptualizing social exclusion in rural Britain, European Planning Studies, 11 (4), s. 461-480.

Philo C., 1992, Neglected Rural Geographies: A Review, Journal of Rural Studies, 8, s. 193-207.

Polska 2030, Wyzwania rozwojowe, 2009, Kancelaria Prezesa Rady Ministrów, dostępne: https:// www.mpips.gov.pl/gfx/mpips/userfiles/_public/1_NOWA\%20STRONA/Aktualnosci/seniorzy/ badania\%20aktywne\%20starzenie/pl_2030_wyzwania_rozwojowe.pdf (DoA: 26.04.2016).

Pomianek I., 2010, Poziom rozwoju społeczno-gospodarczego obszarów wiejskich województwa warmińsko-mazurskiego, Acta Scientarium Polonorum. Oeconomia, 9 (3), s. 227-239.

Pretty J., 1998, O zrównoważonym rozwoju gospodarki lokalnej, Fundacja Wspomagania Wsi, Warszawa.

Putnam R.D., Leonardi R., Nanetti R.Y., 1993, Making democracy work. Civic traditions in modern Italy, Princeton University Press, Princeton.

Putnam R.D., Leonardi R., Nanetti R.Y., 1995, Demokracja w działaniu. Tradycje obywatelskie we współczesnych Włoszech, Wydawnictwo Znak, Kraków.

Reilly M.D., 1990, Free elicitation of descriptive adjectives for tourism image assessment, Journal of Travel Research, 28 (4), s. 21-26.

Roca de Nazaré Oliveira M., 1998, Youth and rural development in Europe - Policy issues and responses in the European Community, [w:] G.A. Truitt (red.), Increasing the involvement of young men and women in rural development in Europe, Food and Agriculture Organization of the United Nations, Rome, s. 1-38.

Rocznik demograficzny, 2013, GUS, Warszawa, dostępne: http://stat.gov.pl/cps/rde/xbcr/gus/rs_ rocznik_demograficzny_2013.pdf, (DoA: 26.04.2016).

Rosner A. (red.), 1999, Typologia wiejskich obszarów problemowych, IRWiR PAN, Warszawa.

Rosner A. (red.), 2002, Wiejskie obszary kumulacji barier rozwojowych, IRWiR PAN, Warszawa.

Rosner A. (red.), 2007, Zróżnicowanie poziomu rozwoju społeczno-gospodarczego obszarów wiejskich a zróżnicowanie dynamiki przemian, IRWiR PAN, Warszawa.

Rye J.F., 2006, Rural youths' images of the rural, Journal of Rural Studies, 22 (4), s. 409-421.

Sakson A., 2003, Kształtowanie się nowej społeczności powiatu słupskiego po 1945 roku na tle przemian społecznych na Ziemiach Zachodnich i Północnych, [w:] A. Czarnik (red.), Obrazy Ziemi Słupskiej. Społeczeństwo-administracja-kultura, Materiały z VII Konferencji Kaszubsko-Pomorskiej, Słupsk, s. 132-139.

Shen G., Shen S., 2014. Study on the psychological problems of left-behind children in rural areas and countermeasures, Studies in Sociology of Science, 5 (4), s. 59-63.

Shortall S., 2008, Are rural development programmes socially inclusive? Social inclusion, civic engagement, participation, and social capital: Exploring the differences, Journal of Rural Studies, 24 (4), s. 450-457.

Sibley D., 1988, Purification of space, Environment and Planning, D: Society and Space, 6 (4), s. 409-421. 
Strzemińska A., Wiśnicka M., (red.), 2011, Młodzież na wsi. Raport z badania, Polsko-Amerykańska Fundacja Wolności, Warszawa.

Szafraniec K., 2005, Młodzież wiejska-młodzież polska: dq̨żenia życiowe i potencjał obywatelski na tle standardów europejskich, Wieś i Rolnictwo, 3, s. 108-122.

Szarfenberg R., 2008: Krytyka i afirmacja polityki społecznej, Wydawnictwo Instytutu Filozofii i Socjologii PAN, Warszawa.

Szymczak M., 2005, Miasto i wieś w Polsce: dystanse w zakresie mieszkaniowych i materialnych warunków życia 1975-1997: studium z socjologii empirycznej, Wydawnictwo Uniwersytetu Łódzkiego, Łódź.

Tarkowska E., 2001, An underclass without ethnicity: the poverty of Polish women and agricultural laborers, [w:] R. Emigh, E. Fodor, I. Szelényi (red.), Poverty, ethnicity \& Gender in Eastern Europe During The Market Transition, Praeger, Westport, s. 83-122.

Vanderbeck R.M., Morse Dunkley C., 2003, Young People's Narratives of Rural-Urban Difference, Children's Geographies, 1 (2), s. 241-259.

Wagner T., 2012, Creating innovators: The making of young people who will change the world, Simon and Schuster, New York.

Wilkin J., 1997, Przekształcenia sektora państwowych gospodarstw rolnych w Polsce w opinii władz lokalnych i mieszkańców „osiedli pegeerowskich”, [w:] K. Korab (red.), Ludzie i ziemia po upadku pegeerów. Analiza socjologiczna i ekonomiczna, Wydawnictwo SGGW, Warszawa, s. 44-75.

Woodward R., 1996, "Deprivation" and "the Rural": An Investigation into Contradictory Discourses, Journal of Rural Studies, 12 (1), s. 55-67.

Woolcock M., Narayan D., 2000, Social capital: Implications for development theory, research, and policy, The World Bank Research Observer, 15 (2), s. 225-249.

\section{Summary}

This paper aims to reflect upon the future direction of development in former PGR (State Agricultural Farms) estates in Poland. Using the post-PGR estate of Chotel (central Poland) as a case study, the authors analyzed and evaluated the potential of the local youth as human resources for future development. It was assumed that the youth, as a social category, will in the nearest future influence the structure of human resources, which in turn will determine both the pace and the direction of change in rural areas. Given that post-PGR estates are considered some of the most problematic settlement forms with respect to rural planning, and given that their adult residents are known to exhibit loose social bonds, intensified enmity and lack of initiative for co-operation, a number of important questions arise. Firstly, what are the specific human resources of the youth in post-PGR estates? Secondly, how do these resources differ from those of their parents? Thirdly, do these resources give hope for future melioration of socio-economic problems inherent of post-PGR estates? The conducted analysis is prognosticating - a quality, which otherwise is extremely difficult to obtain in the context of the studied estates. The paper concludes that with regard to developmental threats in post-PGR estates the attitudes of the youth and the adults are similar. However, considering developmental opportunities the differences are more pronounced, in favor of the youth. 